This document was prepared in conjunction with work accomplished under Contract No. DE-AC09-96SR18500 with the U. S. Department of Energy.

\title{
DISCLAIMER
}

This report was prepared as an account of work sponsored by an agency of the United States Government. Neither the United States Government nor any agency thereof, nor any of their employees, makes any warranty, express or implied, or assumes any legal liability or responsibility for the accuracy, completeness, or usefulness of any information, apparatus, product or process disclosed, or represents that its use would not infringe privately owned rights. Reference herein to any specific commercial product, process or service by trade name, trademark, manufacturer, or otherwise does not necessarily constitute or imply its endorsement, recommendation, or favoring by the United States Government or any agency thereof. The views and opinions of authors expressed herein do not necessarily state or reflect those of the United States Government or any agency thereof.

This report has been reproduced directly from the best available copy.

Available for sale to the public, in paper, from: U.S. Department of Commerce, National Technical Information Service, 5285 Port Royal Road, Springfield, VA 22161, phone: (800) 553-6847, fax: (703) 605-6900

email: orders@ntis.fedworld.gov

online ordering: http://www.ntis.gov/help/index.asp

Available electronically at http://www.osti.gov/bridge

Available for a processing fee to U.S. Department of Energy and its contractors, in paper, from: U.S. Department of Energy, Office of Scientific and Technical Information, P.O. Box 62, Oak Ridge, TN 37831-0062,

phone: (865)576-8401,

fax: (865)576-5728

email: $\underline{\text { reports@ adonis.osti.gov }}$ 


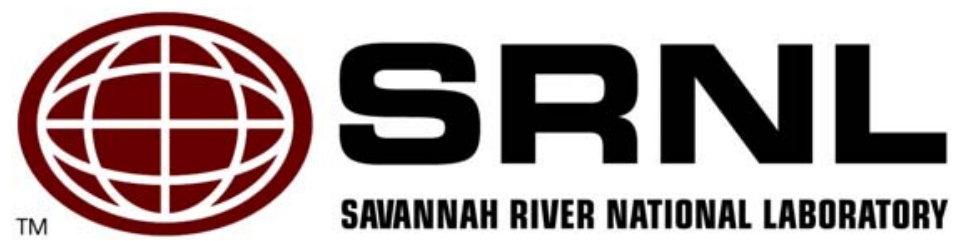

Distribution Category: Unlimited

Retention: Permanent Key Words:

Hydrogen Storage Material

Alanates

\section{A GENERAL INITIAL DECOMPOSITION REACTION FOR COMPLEX METAL HYDRIDES}

R. Tom Walters, John. H. Scogin

Savannah River National Laboratory

Aiken, SC 29808

A paper for publication in the Journal of Alloys and Compounds 
WSRC-MS-2004-00629

\title{
A GENERAL INITIAL DECOMPOSITION REACTION FOR COMPLEX METAL HYDRIDES
}

\author{
R. Tom Walters, John H. Scogin \\ Savannah River National Laboratory \\ Aiken, South Carolina 29808
}

\begin{abstract}
The initial thermally activated decomposition of several complex metal hydride compounds, to a binary alkali or alkaline hydride and a group IIIb metal hydride, appears to share a first step in their decomposition mechanisms. The application of this initial thermochemical decomposition step to several alanate compounds illustrates the generality of this approach. For $\mathrm{LiAlH}_{4}$, the decomposition data fall on the derived distribution plot calculated for $\mathrm{NaAlH}_{4}$.
\end{abstract}

\section{INTRODUCTION}

Many enthusiastic efforts continue to contribute to a solid-state reversible hydrogen storage system that will enable an increased participation in an emerging hydrogen economy [1]. While the use of hydrogen as an energy carrier reduces our dependence on petroleum, solid-state hydrogen storage looms on the energy horizon as a major technical concern. Nevertheless, a number of complex metal hydride materials of composition $\mathrm{A}_{\mathrm{m}}\left(\mathrm{MH}_{\mathrm{x}}\right)_{\mathrm{n}}$, where $\mathrm{A}$ is an alkali or alkaline earth metal $(\mathrm{Li}, \mathrm{Na}, \mathrm{Mg}, \mathrm{K})$, and $\mathrm{M}$ is a group IIIb metal $(\mathrm{B}, \mathrm{Al})$, hold the promise of high weight percent, solid-state hydrogen storage. Examples of these materials under investigation for hydrogen storage properties are $\mathrm{NaAlH}_{4}$ and $\mathrm{Na}_{3} \mathrm{AlH}_{6}, \mathrm{LiAlH}_{4}$ and $\mathrm{Li}_{3} \mathrm{AlH}_{6}$, $\mathrm{Na}_{2} \mathrm{LiAlH}_{6}, \mathrm{Mg}\left(\mathrm{AlH}_{4}\right)_{2}, \mathrm{KAlH}_{4}$ and $\mathrm{K}_{3} \mathrm{AlH}_{6}$, and $\mathrm{LiBH}_{4}$ [2-6]. Although none has emerged as a solid storage panacea, recent advances in transition metal doping have imparted attractive low temperature, reversible, solid-state hydrogen storage properties to these complex metal hydrides [1].

A key to deploying a solid-state hydrogen storage system lies in understanding the fundamental thermochemical processes intrinsic to hydride storage materials. Of late, we proposed a reversible solid-state hydrogen storage mechanism for $\mathrm{NaAlH}_{4}$ [7]. Central to this mechanism is the initial production of a binary alkali hydride $(\mathrm{NaH})$ and an intermediate alane $\left(\mathrm{AlH}_{3}\right)$ that migrates and delivers the evolved hydrogen gas upon decomposition at a titaniumaltered (catalytic) aluminum surface [8]. Then, by the application of high-pressure hydrogen, the same alane species seeks out $\mathrm{NaH}$ and produces the original alanate, thus accounting for the reformation of crystalline $\mathrm{NaAlH}_{4}$. The initial thermally activated decomposition step, producing a binary alkali or alkaline hydride and a group IIIb metal hydride, appears to be a general first step in the decomposition mechanism for this class of complex metal hydride compounds.

The purpose of this short note is to point out that the application of this initial decomposition step to alkali and alkaline alanates demonstrates how some of the accumulating thermo-kinetic data now appearing in the literature for these potentially important solid-state hydrogen storage materials can begin to be rationalized. The proposed shared complex metal hydride initial decomposition step is reaction (1). This reaction initiates an autocatalytic reaction network that continues the decomposition. The reversible capacity of the complex metal hydride, therefore, derives from the decomposition of the intermediate group IIIb metal hydride species [7].

$$
\mathrm{A}_{\mathrm{m}}\left(\mathrm{MH}_{\mathrm{x}}\right)_{\mathrm{n}} \leftrightarrow \mathrm{mAH}_{\mathrm{n}}+\mathrm{nMH}_{\mathrm{x}-\mathrm{m}} \quad(\mathrm{m}=1,3 ; \mathrm{x}=4,6 ; \mathrm{n}=1,2)
$$




\section{LITERATURE EVIDENCE}

Recently, a review of the thermal decomposition of non-interstitial hydrides reported the temperature of thermal decomposition for a series of six alkali alanates correlates well with their standard enthalpy for decomposition, $\Delta H_{d e c}{ }^{\circ}$ [9]. The correlated hydrides are $\mathrm{NaAlH}_{4}$ and $\mathrm{Na}_{3} \mathrm{AlH}_{6}, \mathrm{LiAlH}_{4}$ and $\mathrm{Li}_{3} \mathrm{AlH}_{6}$, and $\mathrm{KAlH}_{4}$ and $\mathrm{K}_{3} \mathrm{AlH}_{6}$. The thermodynamic model for this correlation, based on the Gibbs free energy equation, is as follows:

"When a thermodynamically stable hydride is gradually heated, the entropy factor slowly overcomes the enthalpy contribution, and at a certain temperature, which is the formal hydride's decomposition temperature $\left(T_{\text {dec }}\right)$, the standard Gibbs (energy) of the decomposition, $\Delta G_{d e c}$, falls below zero" [9].

The authors report the $T_{\text {dec }}$ vs $\Delta H_{d e c}{ }^{\circ}$ correlation holds only if the $\Delta H_{d e c}{ }^{\circ}$ values used in the calculation are taken from reaction (1), which involves the initial production of the alkali hydride and the alane $\mathrm{AlH}_{3}$ for these alanates.

In addition, the thermochemistry of sodium alanate is consistent with the initial decomposition step. Lumped activation energies accompany the evolution of hydrogen gas for both neat and titanium-doped $\mathrm{NaAlH}_{4}$ and $\mathrm{Na}_{3} \mathrm{AlH}_{6}$ [10]. The neat materials show very similar activation energies, whereas the doped materials exhibit significantly different values. See Table 1 (titanium dopant added using $\mathrm{TiCl}_{3}$ in this case). Similar activation energies for the evolution of hydrogen are expected if both sodium alanates produce $\mathrm{AlH}_{3}$ as a precursor to hydrogen gas formation. When doped with titanium, the catalyst appears to facilitate the decomposition of $\mathrm{AlH}_{3}$, changing the rate determining step from only the decomposition of $\mathrm{AlH}_{3}$, and including more thermal activation character of the individual alanates [7]. The doped activation energies appear to include the differences in the molecular composition of each alanate and are therefore significantly different, whereas the neat activation energies seem only to include the decomposition of the alane. This discussion derives from the premise that both $\mathrm{NaAlH}_{4}$ and $\mathrm{Na}_{3} \mathrm{AlH}_{6}$ initially produce the alkali hydride and the alane upon initial thermal decomposition, reaction (1). The catalyst then affects the products of the initial decomposition step [7].

Table 1

Activation Energies for hydrogen evolution $\left(125^{\circ} \mathrm{C}\right)^{\mathrm{a}}$

\begin{tabular}{ccc}
\hline $\begin{array}{c}\mathrm{TiCl}_{3} \\
(\mathrm{Mol} \%)\end{array}$ & $\begin{array}{c}\mathrm{NaAlH}_{4} \\
(\mathrm{~kJ} / \mathrm{mole})\end{array}$ & $\begin{array}{c}\mathrm{Na}_{3} \mathrm{AlH}_{6} \\
(\mathrm{~kJ} / \mathrm{mole})\end{array}$ \\
\hline 0 & 118.1 & 120.7 \\
0.9 & 72.8 & 97.1 \\
2 & 79.5 & 97.1 \\
4 & 80.0 & 97.5 \\
6 & 78.5 & 98.2 \\
\hline
\end{tabular}

${ }^{\mathrm{a}}$ Sandrock, et al [10]

Along with the thermal decomposition correlation for lithium alanate, solid-state, ${ }^{27} \mathrm{Al}$ nuclear magnetic resonance data [11] indicate the decomposition path for $\mathrm{LiAlH}_{4}$ includes a direct process described by the initial decomposition step. This NMR data unequivocally show the thermal decomposition of $\mathrm{LiAlH}_{4}$ disagrees with the stoichiometry represented by equation (2); the initial decomposition follows several reaction paths including reaction (1) for $\mathrm{LiAlH}_{4}$.

$$
\mathrm{LiAlH}_{4} \leftrightarrow 1 / 3 \mathrm{Li}_{3} \mathrm{AlH}_{6}+2 / 3 \mathrm{Al}+\mathrm{H}_{2}
$$


Although not included in the correlated thermal decomposition data set, magnesium alanate also appears to decompose initially via a series of light hydrides. Plasma hydrogenation by highflux ion irradiation of $\mathrm{MgAl}$ thin films forms $\mathrm{Mg}\left(\mathrm{AlH}_{4}\right)_{2}$ [6]. Interestingly, the thermal release of hydrogen does not occur in a single step reaction for this alanate. According to the authors, decomposition proceeds by first producing the alane $\mathrm{AlH}_{3}$ and the binary hydride $\mathrm{MgH}_{2}$, reaction (3). The alane then decomposes, producing hydrogen gas.

$$
\mathrm{Mg}\left(\mathrm{AlH}_{4}\right)_{2} \leftrightarrow \mathrm{MgH}_{2}+2 \mathrm{AlH}_{3} \leftrightarrow 2 \mathrm{Al}+3 \mathrm{H}_{2}
$$

\section{DISCUSSION}

Understanding the thermochemical reaction dynamics is the first step in exploiting these materials for hydrogen storage applications. Efforts to identify the intermediate group IIIb metal hydrides are necessary to appreciate fully the reaction mechanisms [12]. The initial decomposition mechanism developed for $\mathrm{NaAlH}_{4}$ [7] appears to be applicable to these complex metal hydride materials, and may provide a fundamental understanding of the reaction kinetics for complex metal hydride materials in general.

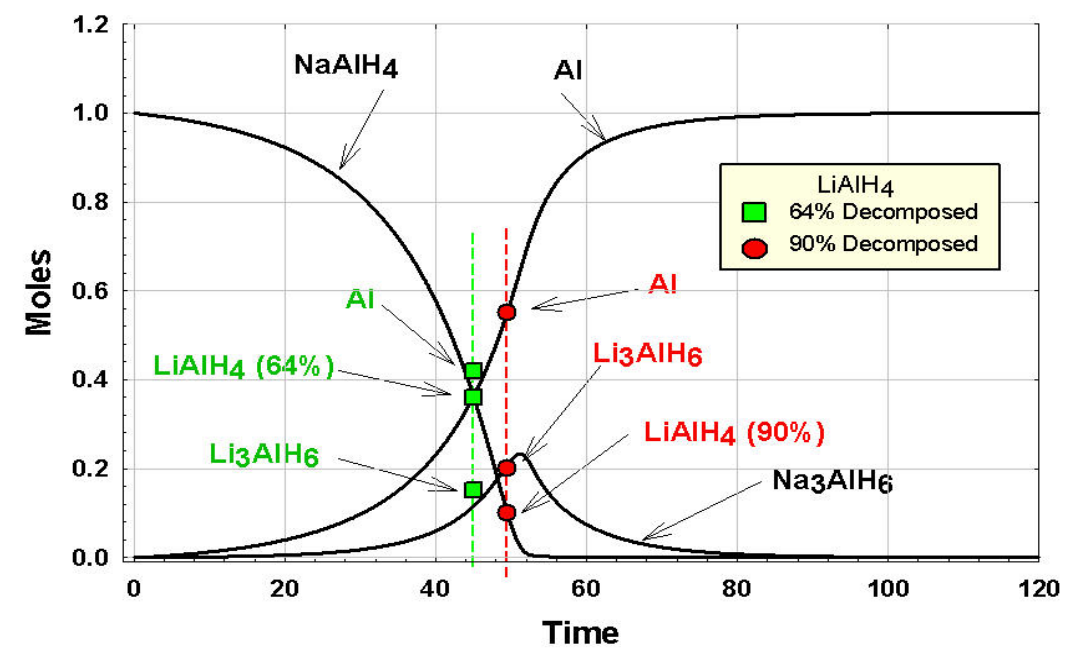

Figure 1. Relative concentration data for the decomposition of $\mathrm{LiAlH}_{4}$ [11] superposed on plots of calculated kinetic evolution of species developed for $\mathrm{NaAlH}_{4}$ [7]. . ., 64\% decomposed; •, $90 \%$ decomposed; solid line, plots generated from decomposition mechanism of $\mathrm{NaAlH}_{4}$.

For example, Wiench, et al. [11] report the relative concentrations of the observed $\mathrm{Al}$ species versus exposure time at $150^{\circ} \mathrm{C}$ for the decomposition of $\mathrm{LiAlH}_{4}$. Figure 1 shows the superposition of those data onto the plots generated from the decomposition mechanism for $\mathrm{NaAlH}_{4}$ [7]. The data are for $\mathrm{LiAlH}_{4}$ at $90 \%$ decomposed (circles) and at 64\% decomposed (squares). The data are in Table 2. Notice the $\mathrm{Li}_{3} \mathrm{AlH}_{6}$ and the bulk $\mathrm{Al}$ concentrations at both degrees of decomposition of $\mathrm{LiAlH}_{4}$ agree very well with the $\mathrm{Na}_{3} \mathrm{AlH}_{6}$ and the bulk $\mathrm{Al}$ for a similar degree of decomposition of $\mathrm{NaAlH}_{4}$ : the data fall on the plots. In this case, the full decomposition mechanism for $\mathrm{NaAlH}_{4}$ appears to be applicable to the $\mathrm{LiAlH}_{4}$ decomposition. 
WSRC-MS-2004-00629

Table 2

Decomposition data for $\mathrm{LiAlH}_{4}$ and $\mathrm{NaAlH}_{4}$, mole $\%$

\begin{tabular}{rcc}
\hline \multicolumn{1}{c}{ Species } & $\begin{array}{c}\mathrm{LiAlH}_{4} \\
\text { Data }^{\mathrm{a}}\end{array}$ & $\begin{array}{c}\mathrm{NaAlH}_{4} \\
\text { Data }^{\mathrm{b}}\end{array}$ \\
\hline$(90 \%)$ & & \\
$\mathrm{MAlH}_{4}$ & 0.10 & 0.10 \\
$\mathrm{Mi}_{3} \mathrm{AlH}_{6}$ & 0.20 & 0.21 \\
$\mathrm{Al}$ & 0.55 & 0.55 \\
$(64 \%) \mathrm{M}$ & & \\
$\mathrm{MAlH}_{4}$ & 0.36 & 0.362 \\
$\mathrm{M}_{3} \mathrm{AlH}$ & 0.15 & 0.12 \\
$\mathrm{Al}$ & 0.42 & 0.36 \\
\hline
\end{tabular}

${ }^{\mathrm{a}}$ Wiench, et al [11]

${ }^{\mathrm{b}}$ Walters and Scogin [7]

\section{CONCLUSION}

These complex metal hydride compounds are examples of lightweight hydride materials currently under investigation for hydrogen storage purposes. The initial decomposition step generalizes some of the accumulating thermo-kinetic data for these potentially important solidstate hydrogen storage materials. For sodium, lithium and potassium alanate, the decomposition temperature correlates well with the decomposition enthalpy only when the initial decomposition step is employed. The initial decomposition step helps in understanding the activation energies for the evolution of hydrogen gas from both $\mathrm{NaAlH}_{4}$ and $\mathrm{Na}_{3} \mathrm{AlH}_{6}$ if $\mathrm{AlH}_{3}$ is a primary product for both decompositions. The thermal decomposition NMR data for $\mathrm{LiAlH}_{4}$ disagrees with the stoichiometric equation (2), but is consistent with reaction paths including reaction (1) for $\mathrm{LiAlH}_{4}$. In fact, the whole decomposition mechanism for $\mathrm{NaAlH}_{4}$ may be applicable to $\mathrm{LiAlH}_{4}$. Finally, the observed decomposition for magnesium alanate follows the initial decomposition step directly.

\section{REFERENCE}

[1] For a few recent efforts, see D. Sun, S.S. Srinivasan, G. Chen, C.M. Jensen, J. Alloys Comp., 373 (2004) 265-269, and references therein; O. Kircher, M. Fichtner, J. Appl. Phys., 95 (12) (2004) 7748 - 7753.

[2] B. Bogdanovic, M. Schwickardi, J. Alloys Comp. 253-254 (1997) 1-9;

[3] J. Chen, N. Kuriyama, Q. Xu, H.T. Takeshita, T. Sakai, J. Phys. Chem., 105 (2001) 11214-11220;

[4] H. Morioka, K. Kakizaki, S. Chung, A. Yamada, J. Alloys Comp., 353 (2003) 310-314;

[5] A. Zuttel, S. Rentsch, P. Fisher, P. Wenger, P. Sudan, Ph. Mauron, Ch. Emmenegger, J. Alloys Comp., 356-357 (2003) 515-520;

[6] L. Pranevicius, D. Milcius, L.L. Pranevicius, G. Thomas, J. Alloys Comp. 373 (2004) 9-15

[7] R.T. Walters, J.H. Scogin, J Alloys Comp., 379 (2004) 135-142

[8] J. Gractz, J.J. Reilly, J. Johnson, A.Y. Ignatov, T.A. Tyson, Applied Physics Letters, 85 (3) (2004) 500-502

[9] W. Grochala, P.P. Edwards, Chem. Rev. 104 (2004) 1283-1315

[10] G. Sandrock, K. Gross, G. Thomas, J. Alloys Comp. 339 (2002) 299-308

[11] a) J.W. Wiench, V.P. Balema, V.K. Percharsky, M. Pruski, J. Solid State Chem., 177 (2004) 648-653; b) See also V.P.Balema, J.W. Wiench, K.W. Dennis, M. Pruski, V.K. Pecharsky, J. Alloys Comp., 329 (2001) 108-114

[12] J. Wang, "Hydride Development for Hydrogen Storage", Fuel Cells \& Infrastructure Technologies Program Review, Philadelphia ,PA 2004 (www.eere.energy.gov/hydrogenandfuelcells/ pdfs/review04/st_9_wang_.pdf) 